\title{
Fatigue failure analysis of HSLA steel sheets holed by conventional and flow drilling processes
}

\section{Análise da fratura em chapas de aço ARBL furadas no processo convencional e por escoamento}

\footnotetext{
${ }^{1}$ Laboratory of Materials and Processes, University of Passo Fundo, Passo Fundo, Rio Grande do Sul, Brasil.

${ }^{2}$ Machining Automation Laboratory, Federal University of Rio Grande do Sul, Porto Alegre, Rio Grande do Sul, Brasil. e-mail: mrpolicena@gmail.com, arieltontrindade@gmail.com, williamseb@ hotmail.com, israel@upf.br gregori.fronza@gmail.com, ajsouza@ufrgs.br
}

\begin{abstract}
Flow drilling process produces bushes for removable joints that can be threaded by forming tapping process, reducing stages in production of components of automobile industry and in construction sheds. High strength and low alloy steels (HSLA) are employed on several applications in the processing industry. Benefits provided by these materials make them an efficient solution, since their high cold resistance allows reducing weight on structures, as well as maintaining the required mechanical properties. The present study evaluated the conventional and friction drilling processes in HSLA steel sheets with a thickness of $4.25 \mathrm{~mm}$. Specimens were subjected to cyclic loadings, with no rework after holemaking, so the resultant characteristics of each process were maintained. Fractured surfaces were analyzed with a scanning electron microscope (SEM) to identify the fracture mechanism in different drilling processes. Fractographies obtained on both processes indicated that the failure mechanism occurred due to ductile fracture resulting from the nucleation, growth and coalescence of micro cavities.
\end{abstract}

Keywords: High strength low alloy steel, conventional drilling, flow drilling, ductile fracture.

\section{RESUMO}

O processo de furação por escoamento produz buchas para uniões removíveis que podem ser roscadas pelo processo de rosqueamento por conformação, reduzindo etapas da produção de componentes da indústria automobilística e em galpões da construção civil. Aços de alta resistência e baixa liga (ARBL) são empregados em variadas aplicações na indústria de transformação. Os benefícios proporcionados por tais materiais tornam-se uma solução eficiente, pois sua alta resistência a frio possibilita a redução de peso em estruturas, além de manter as propriedades mecânicas requeridas. $\mathrm{O}$ presente estudo avaliou os processos de furação convencional e por escoamento em chapas de ARBL com 4,25 mm de espessura. Modelos de corpos de prova foram submetidos a carregamentos cíclicos, sem sofrer retrabalho após o furo, mantendo as características resultantes de cada processo. As superfícies fraturadas foram analisadas com microscópio eletrônico de varredura (MEV) para identificar o mecanismo de fratura nos diferentes processos de furação. As fractografias obtidas em ambos os processos indicaram que o mecanismo de falha ocorreu por fratura dúctil resultante da nucleação, crescimento e coalescência de microcavidades.

Palavras-chave: Aço alta resistência baixa liga; Furação convencional; Furação por escoamento; Fratura dúctil.

\section{INTRODUCTION}

High strength low alloy steels (HSLA) are composed of microstructures formed by hard martensite particles distributed in the ductile ferrite matrix [1]. These materials are compared to dual-phase steels due to their 
high hardening in deformation, high malleability and good surface quality [2]. Contribute to stiffness and weight reduction, being preferred in automotive industry. As their formability characteristics are good, they play an effective role in the production of parts in vehicles such as suspension systems, support elements, longitudinal beams, transverse components and chassis [3]. When these materials are exposed to high temperatures, there is a recrystallization of the microstructure in the heat-affected zone, which directly influences the resistance limit of the material [4].

Drilling is one of the most used processes in manufacturing and constitutes approximately $33 \%$ of the machining. In addition, $25 \%$ of the complete manufacturing process consists of drilling [5]. Drilling is generally one of the last machining processes and has great importance in the economic nature of production [6]. Conventional drilling process uses a defined geometry tool called drill, which can be either high speed steel or carbide with and without coating. In this process, formation and removal of chips occurs. The continuity of material removal is ensured by the relative movement of feed between workpiece and tool, which occurs along a path coincident or parallel to the longitudinal axis of tool [7]. This drilling process leaves burrs on the entry and exit surfaces of the piece. At the entrance, burr forms when material near the drill undergoes plastic flow. At the exit, burr is a part of the ragged material that extends out of exit surface of part. Output burr is much larger than input burr, causing problems in moving parts such as dimensional errors, misalignment and clearance. Burr material is hardened and brittle and can initiate a cracking triggering a failure due to fatigue, as well as compromising safety of workers during handling. To avoid these problems, an additional burr removal (deburring) operation is required, which is the last activity during manufacturing [8].

Flow drilling or friction is an unconventional process of machining, usually dry and employs a special tool of carbide being indicated for ductile and thin-walled materials [9]. When it comes into contact with material, the combination of rotation and axial force generates heat through friction between tool and piece. Temperatures can reach $900{ }^{\circ} \mathrm{C}$ in tool and $700{ }^{\circ} \mathrm{C}$ for in workpiece. Material is transformed into a superplastic state. The process takes place in five stages. The conical tip of the tool approaches and touches the part, the friction with the contact surface produces heat and softens the material of the part, with the material heated the tool penetrates and advances until it touches its shoulder, moving the material leaving a collar (boss) on the top of the part, finally, the tool returns leaving a burr on the bottom of the part, in some cases serves as a fixation point by brazing and in others as a bolted union point [10].

Some papers were developed in flow drilling of several materials. Krishna et al.[11] drilling of 1.0 $\mathrm{mm}$ thick aluminum sheet, where the angle of tool influenced cutting force and torque, and surface with better finishing was obtained in rotation of $2000 \mathrm{rpm}$. Krasauskas [12] drilling of $2.5 \mathrm{~mm}$ thickness sheets of S235 steel, $1.5 \mathrm{~mm}$ and $2.0 \mathrm{~mm}$ thickness AISI 430 stainless steel, $1.5 \mathrm{~mm}$ thickness Al 5652 aluminum alloy, identified that force is considerably dependent on the thickness and the greatest cutting force was obtained when the conical section of tool penetrated the plate, after, the force decreased significantly and torque reached its maximum value. Pantawane and Ahuja [13] in drilling of AISI 1015 steel tubes with $1.0 \mathrm{~mm}$ thickness, the increase of rotation increased the plasticity and decreased dimensional error and surface roughness, with the increase of feed the roughness increased linearly. Kaya et al.[14] in drilling of $2.0 \mathrm{~mm}$ thickness ST12 sheet steel, concluded that cutting force and torque decreased with the increase of rotation, an increase occurred in surface roughness of hole as the feed increased and decreased burr length of exit surface. Özek and Demir [15] in drilling of A7075-T651 aluminum and ST 37 steel sheets, with thicknesses of 2.0, 4.0 and $6.0 \mathrm{~mm}$, verified that ST 37 steel is more suitable for flow drilling because of lower percentage of elongation of material, with roughness values of $0.20 \mu \mathrm{m}$ with $3600 \mathrm{rpm}$ rotation and feed of $75 \mathrm{~mm} / \mathrm{min}$, burr presented in aluminum was of the petal type, which makes difficult the use of the burr in posterior conformation processes. Ku et al.[16] in drilling of AISI 304 stainless steel sheet with $2.0 \mathrm{~mm}$ thickness under optimum operating conditions, burr was approximately three times the thickness of the sheet allowing the same serves as a bearing, brazing connection and threaded for screw fixing. Nagasaka et al. [17] obtained a burr between 3 and 4 times the initial thickness of TRIP steel sheet.

In drilling of HSLA, Siyambaş et al. [5] analyzed the effect of cutting parameters with two $8.0 \mathrm{~mm}$ drills, one with and another without TiAlN coating, concluding that the deviation in diameter increased with the increase of feed for both tools. Siyambaş and Turgut [18] compared the same drills in relation to axial (progressive) force and torque, the increase of feed increased forces and angular moments, for lower cutting speed (10 and $18 \mathrm{~m} / \mathrm{min}$ ), the force and moment differences between the cutting tools were small, and at higher cutting speeds ( 26 and $42 \mathrm{~m} / \mathrm{min}$ ), the forces and moments with coated drills were $43 \%$ lower than the uncoated drills. Sousa et al.[19] modeled the transient heat conduction in drilling process of a $36 \mathrm{~mm}$ thickness HSLA plate, validated the model with thermocouples by measuring the heat flow generated using a coated $10 \mathrm{~mm}$ drill, dry process, with $2000 \mathrm{rpm}$ and feed of $20 \mathrm{~mm} / \mathrm{min}$, obtaining a deviation of $2{ }^{\circ} \mathrm{C}$ between the estimated and measured temperatures. Pereira et al. [20] observed increased roughness with in- 
creased feed rate, in heavy conditions the flank wear and radial wear were greater than $250 \mu \mathrm{m}$ in dry drilling.

In the literature, there are studies related to the properties of HSLA steels after welding. In relation to HSLA welded sheets fracture, with a yield limit of $315 \mathrm{MPa}$ [21], it characterized three distinct regions in high load and cycle fatigue test: void nucleation, growth and coalescence. Also, small elongated dimples were observed in the base metal, characteristics of ductile fracture; coalescence of microcavities was the predominant factor of crack growth in the study with overload stress inducing plastic deformation in HSLA with yield limit of $690 \mathrm{MPa}$ and limit of tensile strength of $790 \mathrm{MPa}$ [22].

Thus, the objective of this work is to analyze the fracture mechanisms in test specimens submitted to fatigue tests after being drilled conventionally and by flow drilling.

\section{MATERIALS AND METHODS}

\subsection{Materials and Equipaments}

Material used in the experiment were USIMINAS LNE 700 high strength low alloy steel sheets with a thickness of $4.25 \mathrm{~mm}$, whose characterization of chemical composition are presented in Table 1 and the mechanical properties in Table 2. Test specimens were prepared according to with ASTM E466, Figure 1.

Table 1: Chemical composition of LNE 700.

\begin{tabular}{cccccccc}
\hline Element & $\mathbf{C}$ & $\mathbf{N b}$ & $\mathbf{T i}$ & $\mathbf{A l}$ & $\mathbf{S i}$ & $\mathbf{P}$ & Others \\
\hline \%weigth & 0.110 & 0.048 & 0.140 & 0.070 & 0.040 & 0.027 & 0.016 \\
\hline
\end{tabular}

Table 2: Mechanical properties of LNE 700.

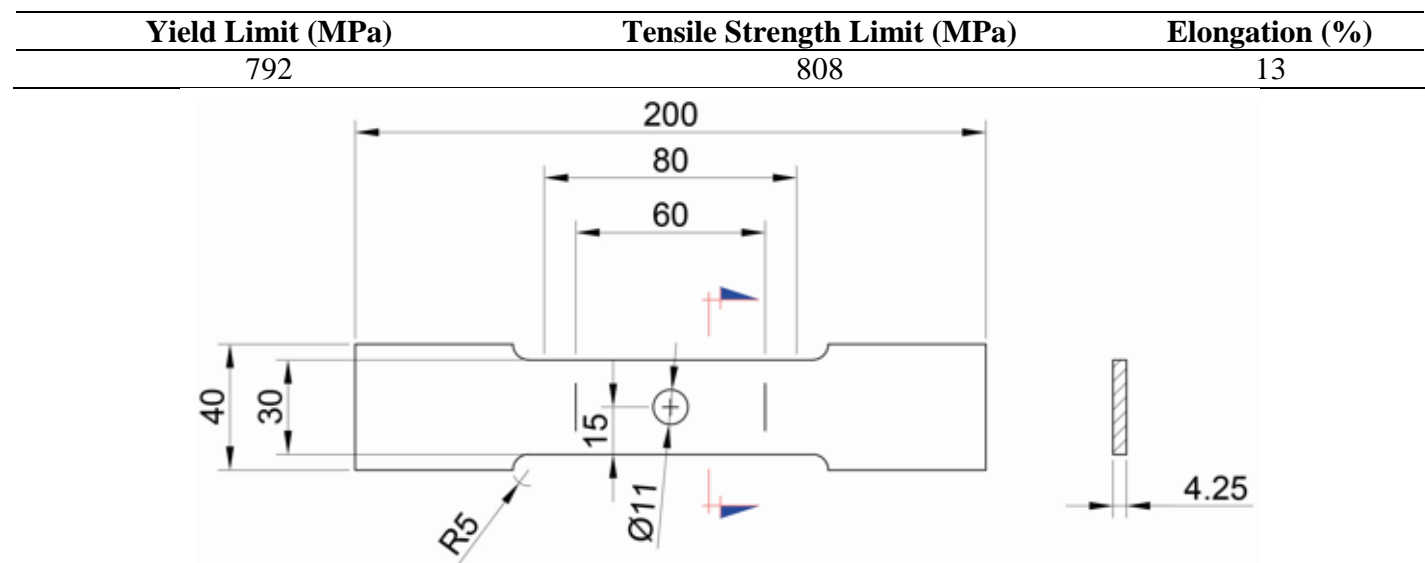

Figure 1: Test specimens dimensions.

\subsection{Drilling Processes}

For conventional drilling, a high-speed helical drill with $11 \mathrm{~mm}$ diameter was used. In flow drilling, a UK40 $11 \mathrm{~mm}$ diameter carbide with TiN coating tool for straight holes was used. For each drilling process, three specimens were used.

Drilling of the specimens was performed in a ROMI D800 CNC. Both processes used a rotation of $850 \mathrm{rpm}$ and feed rate of $120 \mathrm{~mm} / \mathrm{min}$ to ensure that the operating conditions did not interfere in results. Both tests occurred in the vertical position, downward and without pre-drill (full drilling).

Conventional drilling left burrs on the surface that drill entered and on the output surface (Figure 2a). Due to friction generated in flow drilling, geometry of tool assists the localized displacement of material from the part. Some of this material moves upward to form a ring (boss) which is conformed by the tool collar (Figure 2b). Another part of the material flows downward to form the bottom burr (Figure 2c). Drained material forms a bushing that in many cases is used for conformation tapping, removing rivets and nuts from the processes of production of components from automotive, furniture, agricultural and sheds sectors in civil construction [23].

After drilling, fatigue tests were performed on a Shimadzu Push-Pull model Servo Pulser type E ma- 
chine at a frequency of $5 \mathrm{~Hz}$ with $60 \%$ of yield limit. Transversal region to the holes was embedded and prepared for surface analysis with a optical microscope Zeiss, model Scope A1. In flow drilling, four distinct regions were verified as a function of the thermal input of process. Thus, this surface was analyzed in a Tescan Scanning Electron Microscope (SEM), model VEGA 3 LMU, in order to verify occurrence of microstructural changes in HSLA steel. Fractured surfaces of the specimens from both drilling processes were also analyzed in SEM to identify the mechanism that triggered cracking and subsequent collapse.

(a)

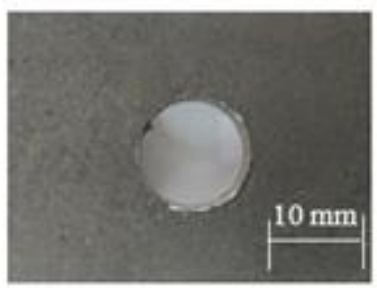

(b)

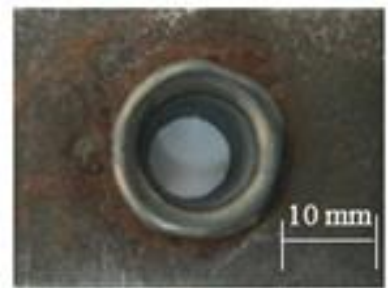

(c)

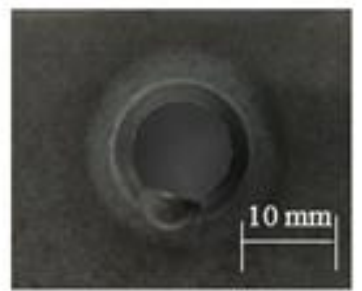

Figure 2: Test specimens: a) Conventional drilling; b) and c) Flow drilling.

\section{RESULTS AND DISCUSSION}

In visual analysis of the cross-section of holes drilled in conventional process (Figure 3a), a deviation in the edge of hole possibly caused by vibration in drill tool or by geometry thereof is realized. In flow drilling, temperature can reach up to $700{ }^{\circ} \mathrm{C}$ in piece [10] and although temperature was not measured during the test, thermal cycles were observed in macrostructure of material that is similar to the welding process (Figure $3 \mathrm{~b}$ ). Regions were divided and their length measured: edge of hole (1) is approximately $0.58 \mathrm{~mm}$; heat-affected Zone - HAZ (2) approximately $1.12 \mathrm{~mm}$; interface (3) between HAZ and base metal (4) is approximately $0.53 \mathrm{~mm}$.

Both drills processes occurred vertically and with tools going from top to bottom. At the entrance of drill, there was no burr formation and profile of the hole indicated that the beginning of removal of chip took place at apparently $45^{\circ}$. There was a deviation in the shape of hole and formation of burr at the exit of drill. Profile of the hole may indicate a geometric error caused by vibration at the entrance of drill in part, which resulted in a hole with misalignment. Another possibility is a difference in width of edges of the drill that also causes a deviation in cut (Figure 3a). In flow drilling there is a deviation in the hole, and there is no removal of chip, material of hole is drained to the top, forming the collar and burr on the bottom with approximately the thickness of the plate $(4.25 \mathrm{~mm})$. Final shape gave the piece an increase in thickness totaling approximately $10 \mathrm{~mm}$, which makes the process beneficial for threads conformation with use of taps (Figure $3 \mathrm{~b}$ ).

(a)

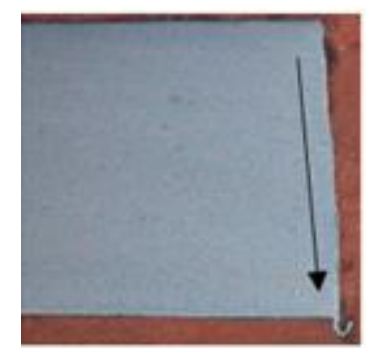

(b)

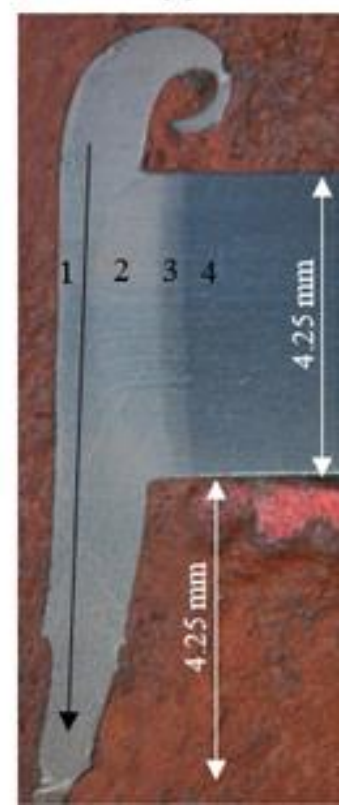


Figure 3: Hole edge region: a) conventional; b) flow drilling.

In conventional drilling, the material with moderate ductility tends to elongate to some extent during burr formation, resulting in a large burr height. The burr is undesirable and requires a subsequent process for its removal. Kim et al.[26] observed a burr height of $0.18 \mathrm{~mm}$ in the drilling of AISI 4118. Where as in flow drilling, burr is beneficial, it increases the thickness of sheet for materials with high ductility [16,17] and good mechanical properties, allowing a process of conforming threads or brazing in tubes. Özek and Demir [15] measured a burr height of 6 to $7 \mathrm{~mm}$ in flow drilling ST 37 steel with 4mm thickness. Miller et al. [27] measured a burr height of $2.96 \mathrm{~mm}$ to sheet AISI 1020 with $1.56 \mathrm{~mm}$ thickness and 4.12 to sheet AISI 4130 with $1.43 \mathrm{~mm}$ thickness. Matysiak and Bernat [30] obtained burr height $5.96 \mathrm{~mm}$ in low carbon steel sheet $2 \mathrm{~mm}$ thickness.

Figure 4 shows images of the surface of material, in flow drilling region, obtained through SEM: a) hole edge; (b) HAZ; (c) base metal; (d) interface region between HAZ and base metal. For base metal there are elongated grains characteristic of HSLA steels conforming process. As the points of analysis approach the center of hole, a recrystallization of grains relative to the high temperatures generated in process is noticed (a). This phenomenon is also evident in heat-affected zone (b). In interface region between base metal and HAZ (d) it is possible to verify the transition between recrystallized grains (left side) and hardened and equiaxed grains (right side).

This analysis was aimed at verifying the occurrence of microstructural changes from transformation phase and mechanisms of recovery, recrystallization and grain refining as a function of thermal input from flow drilling process. In fatigue test, flow drilling test specimen supported approximately 4 times more load cycles [24]. This paper also verified micro hardness of regions that did not present statistically significant differences. Miller et al. [27] verified a region of relatively fine grained, equiaxed grains extend radially from the hole surface. Inside this subsurface region, a larger region of elongated grains is visible.

a) Hole edge

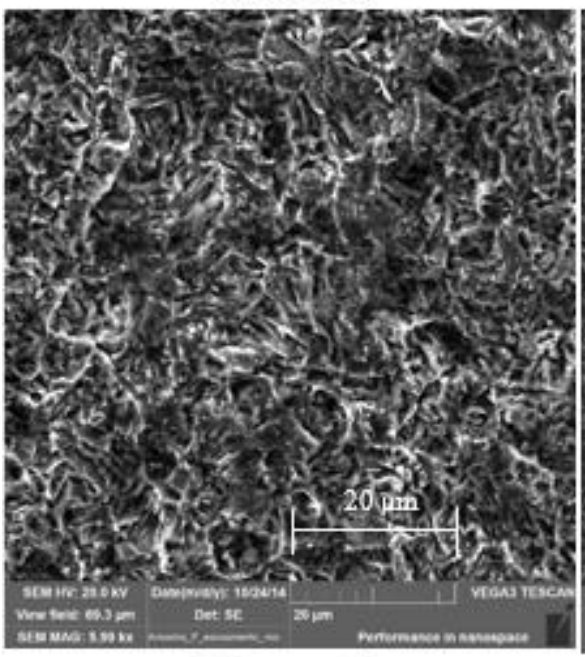

c) Base metal

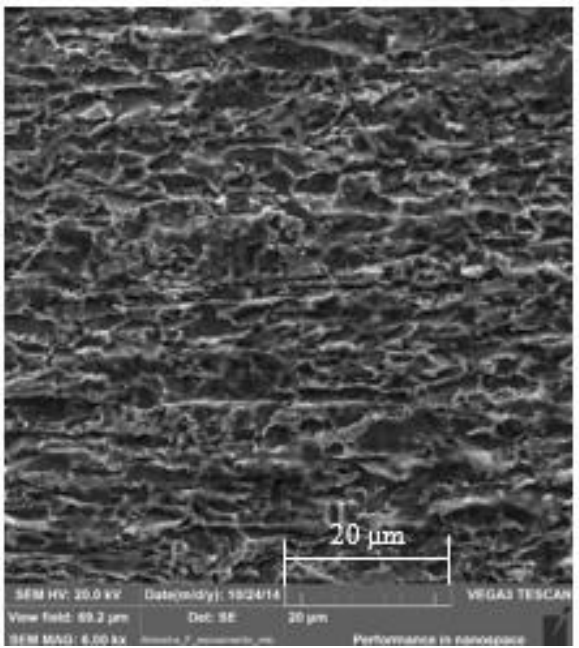

b) $\mathrm{HAZ}$

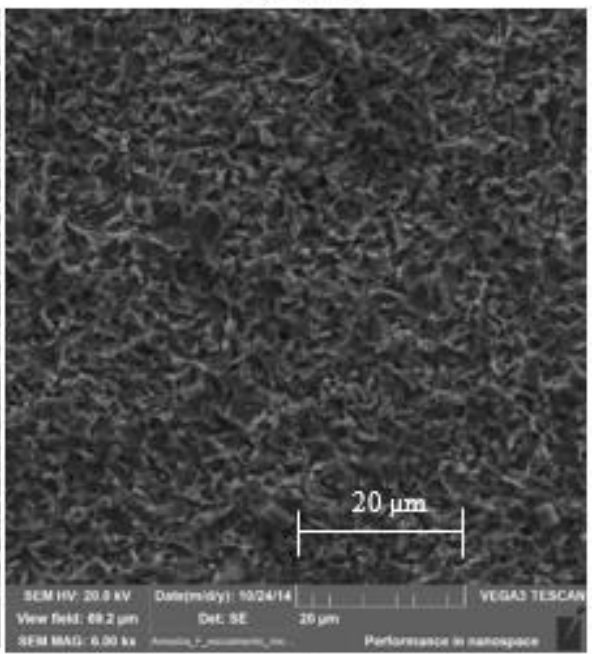

d) Interface between base metal and HAZ

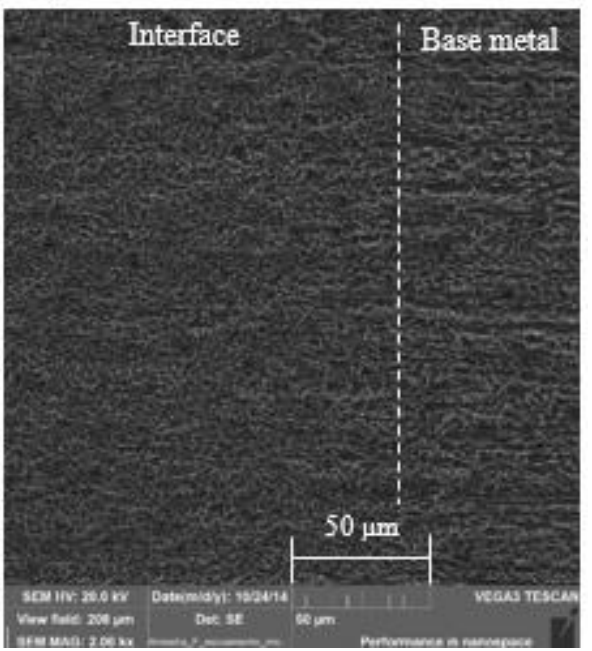


Figure 4: SEM images realized in flow drilling test specimens.

In analysis of fractured surface, it was observed that in conventional drilling the crack began from the edge of hole towards the end of test specimens. In addition, beginning of propagation of this crack was accentuated by surface roughness, according to Figure 5a. Number one indicates the side of the workpiece that fracture began. In Fig. 5b, dimples are more evident in relation to fractography of test specimen, evidencing rupture of a material with good ductility when subjected to cyclic fatigue test.

Analyzing the fracture provided by fatigue test on flow drilling piece, it is observed that crack began in burr region (HAZ) towards the center of hole (Figure 6a). For Shigley et al. [25] the ratio and direction of propagation of fatigue crack are controlled primarily by localized stresses and by the structure of material in that region. Figure $6 \mathrm{~b}$ reveals presence of remaining dimples of nucleated cavities, the coalescence of micro cavities followed by their union characterizes ductile type fracture. Fatigue test in HSLA welded, Zhang et al. [29] reported multiple micro cracking more severe in the HAZ indicating a change in material properties with micro plastic failure through micro void coalescence.
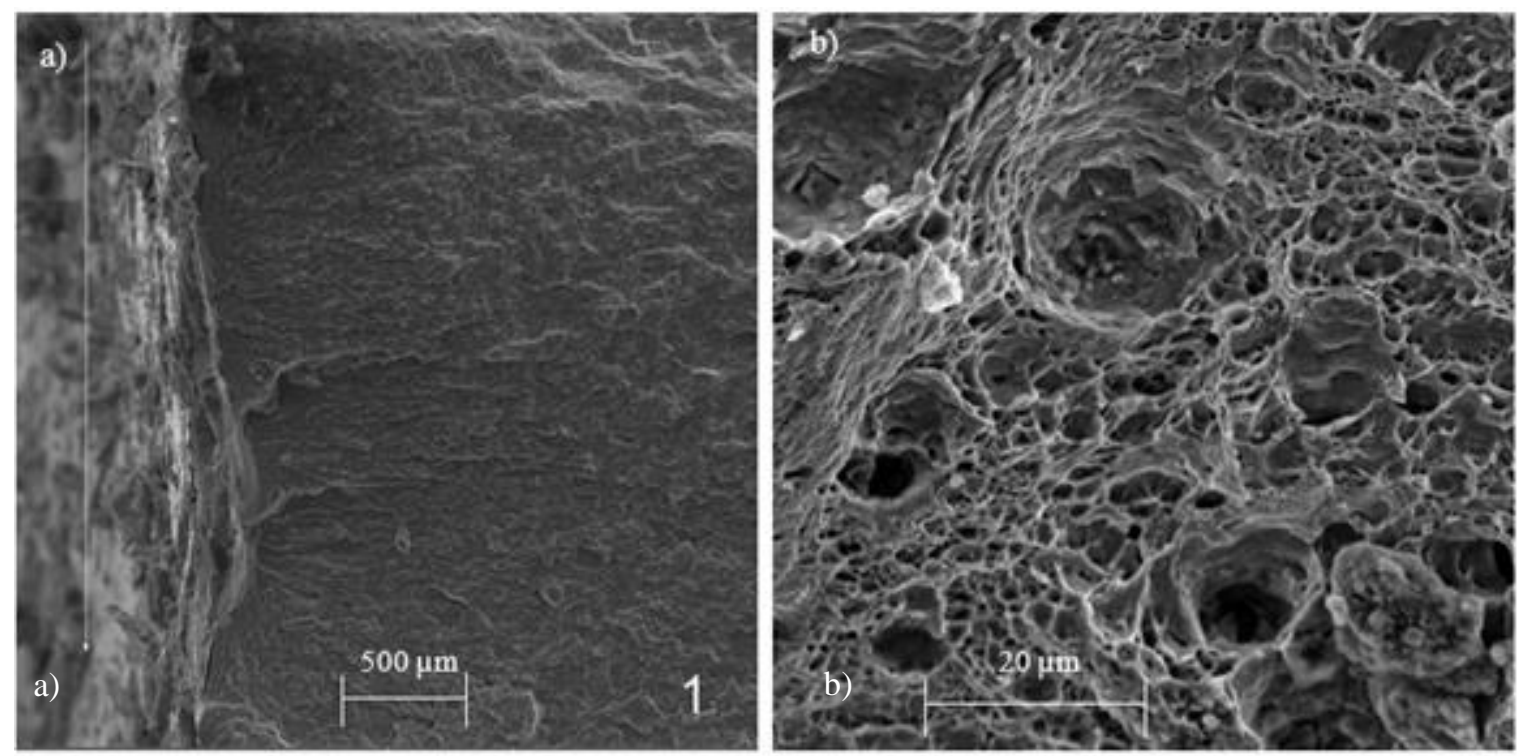

Figure 5: Fractography in region where fracture began in conventional drilling: a) edge; b) dimples.
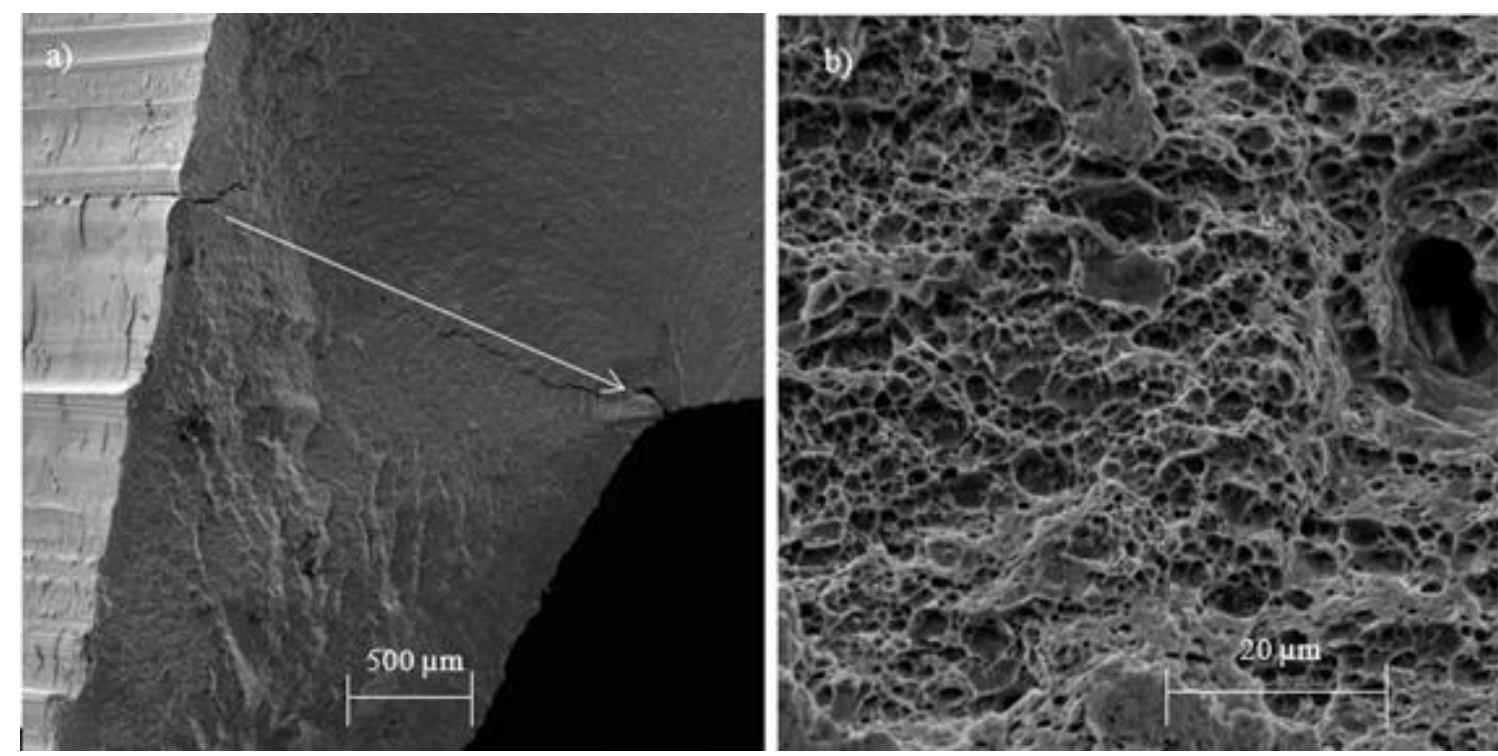

Figure 6: Fractography of region where initiated the fracture in flow drilling: a) burr; b) dimples. 
Fractographies indicate that the mechanism of fracture in both test specimens models occurred in the same way. In conventional drilling, coalescence of micro cavity was significant for failure of test specimen, corroborating with what was found by [21, 22], being that the dimples more evident. In friction drilling the dimples are smaller. Nathan et al. [28] related fine and secondary dimples with substantial dissimilarity in size and alignment of the dimples in the fracture surface which was not found in both cases. The conventional drilling presented a greater number of voids, which may indicate that the ductile fracture occurred with a considerable reduction in the tensile strength.

\section{CONCLUSIONS}

In this work, specimens of HSLA sheets with $4.25 \mathrm{~mm}$ thickness were drilled conventional and friction. After, were submitted to fatigue tests and the fracture mechanisms investigated. Both drilling processes generated burrs, which in drilling with drill bit is undesirable while in friction drilling increases sheet thickness to materials with high ductility. The heat flow in this process produced different regions that resulted in changes in the microstructure. Temperature from flow drilling could influence the embrittlement of material, but the formation of ring (boss) that is a characteristic of the process varies according to geometry of tool, acted as a barrier for the propagation of cracks reducing tension concentration factor in the hole. The mechanism of fracture in both processes occurred due to ductile fracture resulting from the nucleation, growth and coalescence of micro cavities. The dimples became more evident and with greater voids in conventional drilling. In friction drilling, the number of voids decreased.

\section{BIBLIOGRAPHY}

[1] ERDOGAN, M., "The Effect of Austenite Dispersion on Phase Transformation in Dual Phase Steels", Scripta Materialia, v. 48, n. 5, pp. 501-506, Mar. 2003.

[2] DZUPON, M., PARILAK, L., KOLlarovA, M., et al., "Dual Phase Ferrite-Martensitic Steel Micro Alloyed With V-Nb", Metalurgija, v. 46, n. 1, pp. 15-20, Dec. 2006.

[3] KADKHODAPOUR, J., BUTZ, A., RAD, S. Z., "Mechanisms of void formation during tensile testing in a commercial, dual-phase steel”, Acta Materialia, v. 59, n. 7, pp. 2575-2588, Apr. 2011.

[4] COSTA, J. D. M., FERREIRA, J. A. M., ABREU, L. P. M., "Fatigue behaviour of butt welded joints in a high strength steel”, Procedia Engineering, v. 2, n. 1, pp. 697-705, Apr. 2010.

[5] SIYAMBAŞ, Y., BAYRAKTAR, Ş., TURGUT, Y., "Investigation of the Effects of Cutting Parameters on Diameter Deviation in Drilling of HSLA Steel", Turkish Journal of Electromechanics \& Energy, v. 2, n. 1, pp. 3-8, Jan. 2017.

[6] LI, R., SHIH, A. J., "Finite element modeling of high throughput drilling of Ti-6Al-4V", Transactions of NAMRI/SME, v. 35, pp. 73-80, 2007.

[7] DINIZ, A. E., MARCONDES, F. C., COPPINI, N. L., Tecnologia da usinagem dos materiais, 8 ed., São Paulo, Artiliber, 2013.

[8] MIN, S., KIM, J., DORNFELD, D. A., "Development of a drilling burr control chart for low alloy steel, AISI 4118”, Journal of Materials Processing Technology, v. 113, n. 1, pp. 4-9, Jun. 2001.

[9] NARDI, D., LACALLE, L. N. L., LAMIKIZ, A., "Taladro por fricción en aceros de doble fase”, Revista Metalurgia, v. 48, n. 1, pp. 13-23, Jan. 2012.

[10] PRABHU, T., ARULMURUGU, A. M., "Experimental and analysis of friction drilling on aluminium and copper", International journal of mechanical engineering and technology (IJMET), v. 5, n. 5, pp. 130139, Mai. 2014.

[11] KRISHNA, P. V. G., KISHORE, K., SATYANARAYANA, V. V., "Some investigations in friction drilling AA6351 using high speed steel tools", ARPN Journal of Engineering and Applied Sciences, v. 5, n. 3, pp.11-15, Mar. 2010.

[12] KRASAUSKAS, P., "Experimental and statistical investigation of thermo-mechanical friction drilling process", Mechanika, v. 17, n. 6, pp. 681-686, 2011.

[13] PANTAWANE, P. D., AHUJA, B. B., "Experimental investigations and multi-objective optimization of friction drilling process on AISI 1015”, International journal of applied engineering research, v. 2, n. 2, pp. 448-461, 2011.

[14] KAYA, M. T., AKTAS, A., BEYLERGIL, B., et al., "An experimental study on friction drilling of st12 steel” Transactions of the Canadian Society for Mechanical Engineering, v. 38, n. 3, pp. 319-329, 2014. 
[15] ÖZEK, C., DEMIR, Z., "Investigate the Surface Roughness and Bushing Shape in Friction Drilling Of A7075-T651 and St 37 Steel", TEM journal, v. 2, n. 2, pp. 170-180, Mai. 2013.

[16] KU, W. L., HUNG, C. L., LEE, S. M., et al., "Optimization in thermal friction drilling for SUS 304 Stainless Steel", International Journal of Advance Manufacturing Technology (IJAMT), v. 53, n. 9, pp. 953944, Apr. 2011.

[17] NAGASAKA, A., MATSUSHIMA, T., HASEBE, S., et al., "Effect of thermal drilling condition on burring in ultrahigh strength TRIP sheet steels", International Conference Super-High Strength Steels, 2, Milano, pp. 1-9, 2010.

[18] SIYAMBAŞ, Y., TURGUT, Y., "HSLA DIN EN 10149 Çeliğin Delinmesinde Kesme Parametrelerinin Eksenel Kuvvet ve Momente Etkilerinin Deneysel Araştırılması", Electronic Journal of Machine Technologies, v. 12, n. 2, pp. 41-49, 2015.

[19] SOUSA, P. F. B., BORGES, V. L., PEREIRA, I. C., SILVA, M. B., GUIMARÃES, G., "Estimation of heat flux and temperature field during drilling process using dynamic observers based on Green's function", Applied Thermal Engineering, v. 48, n. 1, pp. 144-154, Dec. 2012.

[20] PEREIRA, A., RIVEIRO, E., MARTÍNEZ, J., PÉREZ, J. A., "Machinability of high-strength low-alloy steel D38MSV5S forged crankshafts", Archives of Mechanical Technology and Automation, v. 34, n. 4, pp. 45-57, 2014.

[21] KAMRAN, A., KULTHIDA, S., JWO, P., "Fatigue behavior of laser welds in lap-shear specimens of high strength low alloy steel sheets", International Journal of Fatigue, v. 61, n. 1, pp. 283-296, Apr. 2014.

[22] CHUNGUO, Z., XIAOZHI, H., PENGMIN, L., GAIPING, Z., "Tensile overload-induced plastic deformation and fatigue behavior in weld-repaired high-strength low-alloy steel", Journal of Materials Processing Technology, v. 213, n. 11, pp. 2005-2014, Nov. 2013.

[23] ECKHARDT, M., Relação entre processo, microestrutura e propriedades mecânicas na furação por escoamento de aços de baixo carbono. Tese de D.Sc., UFSC/Programa de Engenharia Mecânica, 2003.

[24] POLICENA, M. R., TRINDADE, A., FRIPP, W. H., ISRAEL, C. L., "Os efeitos da furação convencional e por escoamento em chapas de aço", Corte e conformação de metais, n. 142, pp. 18-21, Fev. 2017.

[25] SHIGLEY, J. E., MISCHKE, C. R., BUDYNAS, R. G., Projeto de Engenharia Mecânica, 7 ed., Porto Alegre, Bookman, 2005.

[26] KIM, J., MIN, S., DORNFELD, D. A., "Optimization and control of drilling burr formation of AISI 304L and AISI 4118 based on drilling burr control charts", International of Machine Tools \& Manufacture, v. 41, n. 7, pp. 923-936, May 2001.

[27] MILLER, S. F., BLAU, P. J., SHIH, A. J., "Microstructural Alterations Associated With Friction Drilling of Steel, Aluminum, and Titanium", Journal of Materials Engineering and Performance, v. 14, n. 5, pp. 647-653, Oct. 2005.

[28] NATHAN, S. R., BALASUBRAMANIAN, V., MALARVIZHI, S., RAO, A. G., "Effect of welding processes on mechanical and microstructural characteristics of high strength low alloy naval grade steel joints", Defence Technology, v. 11, n. 3, pp. 308-317, Sep. 2015.

[29] ZHANG, C., VYVER, S., HU, X., LU, P., "Fatigue crack growth behavior in weld-repaired highstrength low-alloy steel”, Engineering Fracture Mechanics, v. 78, n. 9, pp. 1862-1875, June 2011.

[30] MATYSIAK, W., BERNAT, L., "Shaping the edges using flowdrill technology", METABK, v. 54, n. 1, pp. 235-238, Jan. 2015.

\section{ORCID}

Mauricio Rodrigues Policena

Arielton Vinícius Trindade

Charles Leonardo Israel

William Haubert Frip

Gregori Fronza

André João de Souza https://orcid.org/0000-0002-2902-0908

https://orcid.org/0000-0002-1220-8189

https://orcid.org/0000-0001-9422-2824

https://orcid.org/0000-0003-1593-3383

https://orcid.org/0000-0002-0106-0908

https://orcid.org/0000-0001-5649-7333 